INTERNATIONAL FOOD

POLICY RESEARCH INSTITUTE

\title{
Advancing Agriculture in Developing Countries through Knowledge and Innovation
}

\section{SYNOPSIS}

\section{of an International Conference}

Kwadwo Asenso-Okyere, Kristin Davis, and Dejene Aredo 
The International Food Policy Research Institute (IFPRI) was established in 1975. IFPRI is one of 15 agricultural research centers that receives its funding from governments, private foundations, and international and regional organizations, most of which are members of the Consultative Group on International Agricultural Research (CGIAR).

IFPRI's research, capacity strengthening, and communications work is made possible by its financial contributors and partners. IFPRI receives its principal funding from governments, private foundations, and international and regional organizations, most of which are members of the Consultative Group on International Agricultural Research (CGIAR). IFPRI gratefully acknowledges generous unrestricted funding from Australia, Canada, China, Finland, France, Germany, India, Ireland, Italy, Japan, the Netherlands, Norway, South Africa, Sweden, Switzerland, the United Kingdom, the United States, and the World Bank.

This synopsis is based on a consultative conference held in Addis Ababa, Ethiopia, in April 2008. IFPRI gratefully acknowledges the contributions of the German Agency for Technical Cooperation (GTZ) www.gtz.de, the ICT-KM program of the CGIAR www.ictkm.cgiar.org, the Japan International Cooperation Agency (JICA) www.jica.go.jp, Research Into Use (RIU) www.researchintouse.com, the Technical Centre for Agricultural and Rural Cooperation (CTA) www.cta.int, and the World Food Programme (WFP) www.wfp.org.

The authors are grateful for the support of Jifar Tarekegn in the preparation of this synopsis. 
ADVANCING

AGRICULTURE IN

DEVELOPING COUNTRIES

THROUGH KNOWLEDGE

AND INNOVATION

SYNOPSIS OF AN

INTERNATIONAL CONFERENCE

Kwadwo Asenso-Okyere, Kristin Davis,

and Dejene Aredo

International Food Policy Research Institute

Washington, D.C., November 2008 
ISBN: 10-digit: 0-89629-780-2 13-digit: 978-0-89629-780-7

DOI: $10.2499 / 0896297802$

Copyright (C) 2008 International Food Policy Research Institute. All rights reserved. Sections of this report may be reproduced without the express permission of but with acknowledgment to the International Food Policy Research Institute. Contact ifpri-copyright@cgiar.org for permission to reprint.

International Food Policy Research Institute

2033 K Street, NW, Washington, DC 20006-1002, USA

Telephone: +1-202-862-5600; Fax: +1-202-467-4439

www.ifpri.org 


\section{CONTENTS}

\begin{tabular}{l} 
I \\
INTRODUCTION \\
\hline UNDERSTANDING KNOWLEDGE AND INNOVATION \\
Concepts in Innovation \\
Knowledge Creation and Management \\
Learning for Innovation \\
Innovation Approaches \\
3 \\
\hline ORGANIZATIONAL INNOVATION \\
\hline TECHNOLOGICAL INNOVATION \\
Technical Knowledge \\
Enhancing Investment in Research and Development \\
BNSTITUTIONAL INNOVATION
\end{tabular}

The Nature of Institutions

Partnerships Facilitate Innovation

$$
6
$$

POLICY INNOVATION

7

STRENGTHENING CAPACITIES FOR KNOWLEDGE AND INNOVATION

8 
FIGURE

I. Diagrammatic Representation of Knowledge Management

BOXES

I. Rural Knowledge Networks and Agricultural Innovation: The Case of Bolivia 8

2. Demand for Advisory Services in Africa: The Cases of Nigeria and Uganda 9

3. A Decentralized, Farmer-Led, Market-Driven Extension System: The Case of India 10

4. Monsanto Agricultural Technology 12

5. Social Networks in Knowledge Sharing $\quad 15$ 6. Adding Value to Tomato Production in Morocco: A Model of Partnership
in Knowledge and Risk Sharing

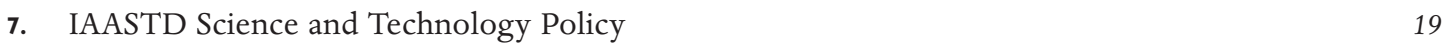

8. Developing Capacity for No-Till Packages for Small-Scale Farmers in Argentina 21

9. Building the Capacity to Forge Public-Private Partnerships in Latin America 22

10. Developing Farmer-Based Organizations in South India 22 


\section{INTRODUCTION}

bout 75 percent of the world's poor people live in
rural areas, and most of them are involved in farming. Agricultural development in these areas is often constrained by issues of access to appropriate technologies; immense "institutional weaknesses"; and deep problems with the organization and management of research, education, and extension systems. Many countries and agricultural systems thus remain mired in underdevelopment and face major barriers to the use of knowledge and innovation for development. Despite this, however, there are examples of organizational, technological, institutional, and policy innovations that are transforming agriculture and leading to growth and development. Important lessons can be learned and scaled up from the successes that are occurring, as well as from examining cases that did not work. Fortunately, awareness of the vital role that agriculture plays in development is increasing among policymakers and donors in most countries, in part as a result of the current global food-price crisis and in response to the publication of the 2008 World Development Report, which focuses on agriculture. Agriculture remains crucial to developing countries; it has been observed that GDP growth from agriculture benefits the incomes of poor people two to four times more than GDP growth in other sectors of the economy.

In science, revolutionary advances in the biological and information fields have the potential to enhance the competitiveness of market-oriented smallholders and to overcome disease and the effects of drought in production systems. The setting for institutional and organizational innovation is changing rapidly as well, often involving the entry of new players. The new world of agriculture is opening up space for a wider range of actors in innovation, including farmer organizations, the private sector, and civil society. Linking technological progress with organizational, institutional, and policy innovations and with markets to engage this diverse set of actors is important for future productivity growth.

The 2008 World Development Report emphasizes the importance of knowledge in bringing about innovation. The report refers to a series of mutually supportive, often knowledge-intensive, innovations that enable a country's agricultural producers to move up the value chain in international agricultural export markets. The strategy is to bring about new

\footnotetext{
${ }^{1}$ In this context, "institutions" are defined as the system of rules that constitute the environment within which innovation occurs.
} 
or adapted knowledge to produce innovations that increase agricultural productivity and reduce poverty.

In April 2008, the International Food Policy Research Institute (IFPRI) held an international consultative conference in Addis Ababa, Ethiopia, entitled "Advancing Agriculture in Developing Countries through Knowledge and Innovation." The objectives of the conference were (a) to showcase research results and other experiences in agricultural knowledge and innovation for development; (b) to demonstrate useful methods and applications of the knowledge base for scaling up and out; (c) to provide a forum for researchers, policymakers, and practitioners from different sectors to discuss issues in agricultural knowledge and innovation; (d) and to identify areas for further research, advocacy, and international cooperation in knowledge and innovation. The conference contributed to the higher goal of improving smallholder livelihoods worldwide through sound policy and better application of knowledge and innovation for development. Smallholders and other rural people will ultimately benefit through improved policy and research specifically addressing the complex agricultural system in which they are embedded, and through wider and more consistent application of knowledge and innovation for development.

This document is a synopsis of the conference presentations and discussions on ideas and experiences relating to knowledge and innovation among different innovation agents (including public, private, and civil sectors). Papers were presented by agricultural researchers, development practitioners, policymakers, nongovernmental project managers, and private entrepreneurs. The synopsis is one of a number of conference outputs and is intended to provide a concise overview of the outcomes. Topics dealt with include (a) the role of knowledge and innovation in meeting the challenges of reducing poverty in developing countries, (b) the roles different actors play in agricultural development and poverty reduction, and (c) whether new and appropriate technologies and policies are available for the purpose of reducing rural poverty. Accordingly, in endeavoring to promote agricultural knowledge and innovation in developing countries, it is expected that useful lessons will be drawn from the issues presented and discussed in this synopsis.

The next section reviews the concepts of knowledge and innovation and their relevance to poverty reduction; Section 3 focuses on organizational innovation; Section 4 deals with technological innovation; and Section 5 looks at institutional innovation. Section 6 presents policy innovations; Section 7 discusses capacity building for the innovation process; and Section 8 offers conclusions and a way forward. Conference proceedings may also be found at http://www.ifpri.org/events/ conferences/2008/20080407.asp. 


\section{2}

\section{UNDERSTANDING}

\section{KNOWLEDGE AND}

\section{INNOVATION}

\section{CONCEPTS IN INNOVATION}

nnovations are new ideas, practices, or products that are successfully introduced into economic or social processes. Innovations can take the form of technologies, organizations, institutions, or policies and involve the extraction of economic, ecological, and social value from knowledge. The process of innovation further involves putting ideas, knowledge, and technology to work in a manner that brings about a significant improvement in performance. It is not just an idea, but a workable idea.

In agriculture, innovation can include new knowledge or technologies related to primary production, processing, and commercialization, which can positively affect the productivity, competitiveness, and livelihoods of farmers and others in rural areas.

\section{KNOWLEDGE CREATION AND MANAGEMENT}

Knowledge has become a key factor in development, and this trend is set to intensify. In the 21 st century, knowledge accumulation and application will drive development processes. How can knowledge best be managed so that it brings about the innovations
... when knowledge successfully transformed it can yield innovation, which in turn enhances the competence, productivity, competitiveness, and livelihoods of agents in the value chain. necessary for pro-poor agricultural growth and development?

Knowledge, which can be defined as organized or processed information or data, is fundamental in the pursuit of innovation. Such knowledge can be tacit or codified, and indigenous or scientific, depending upon how and where it is acquired. Tacit knowledge forms gradually over time through repetition and recurrent interactions; it is situated in systems of ongoing practices and routines; and it is a product of social, cultural, economic, and political conditions. Thus, tacit knowledge depends on learning through training and experience. On the other hand, codified knowledge is partly transferable and universal. Knowledge can be acquired only through some form of participation in practice, and it is transformed by the process of circulation itself. The production of knowledge is achieved by exposing what is known to what is not known. Increased mobility of knowledge has made recycling knowledge easier.

What is important is the presence of knowledge systems that either enable or constrain the creation, accumulation, use, and sharing of knowledge in support of innovation. Emphasis has shifted toward putting knowledge to use; thus, the capacity to innovate is a function of the behavior of systems for producing, 
FIGURE I. Diagrammatic Representation of Knowledge Management

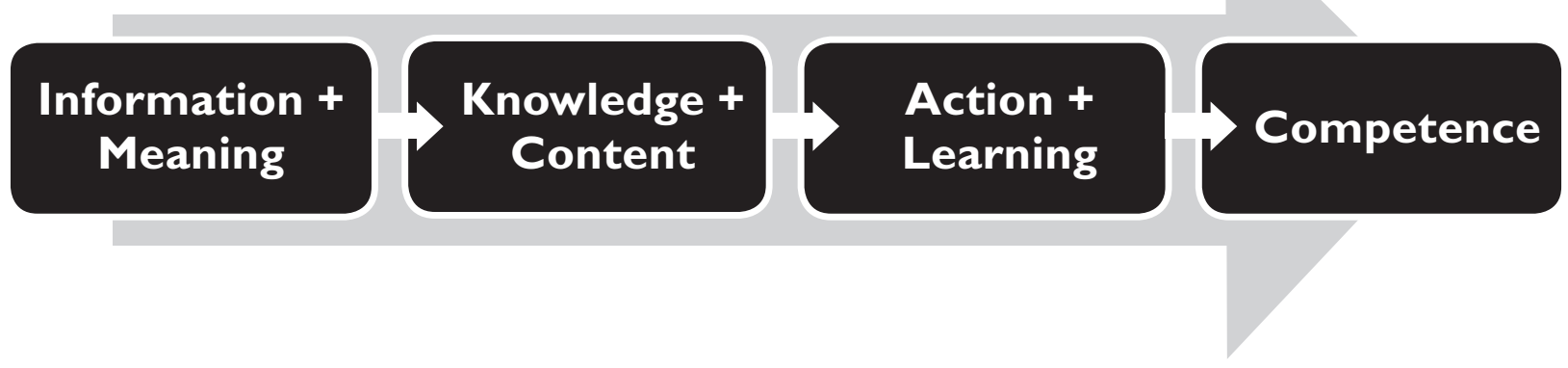

absorbing, and using knowledge. The actions toward sustainable development require a mix of scientific, economic, social, and political knowledge.

Knowledge has to be managed if it is to be useful. The driving force behind knowledge management is improved competence (efficiency) and competitiveness, which largely come through some action and learning (Figure 1).

\section{LEARNING FOR INNOVATION}

Learning to accumulate knowledge is central to an innovation system. Four types of learning to accumulate knowledge can be distinguished: (a) learning as a joint product with other activities and production and use of technologies (that is, "learning by doing"); (b) learning as a result of using a product, which feeds back into product design and development (that is, "learning by using"); (c) learning as a result of a formal discovery process, typically organized around a direct research and development (R\&D) program or acquired through different means including formal education and training arrangements (that is, "learning through formal means"); and (d) learning through self-education (that is, through reading books, visiting websites, listening to the radio, and so on).

Conducive learning platforms should be created so that the stock of knowledge can be expanded through continuous, life-long learning. Knowledge can be obtained globally and used locally. For instance, knowledge needed to develop the nascent floriculture sector in Ethiopia is obtained globally, and in-country capacity is being built to expand the industry.

\section{INNOVATION APPROACHES}

\section{National Agricultural Research Systems}

National agricultural research systems (NARSs) comprise agricultural research institutes and higher education institutions, which carry out agricultural research within a given country and effect technological change through a linear model of research, development, and extension. The system assumes that agricultural knowledge originates from a known source (the scientific researcher) and flows to an end user (the farmer) in a process that is largely exogenous and unchanging.

\section{Agricultural Knowledge and Information Systems}

Agricultural knowledge and information systems (AKISs) highlight the linkages among research, education, and extension in generating knowledge and fostering technological change. The system focuses on the dynamics of knowledge dissemination through extension and therefore recognizes a link between researchers and end users. The AKIS perspective 
tends to be less linear than the NARS approach. However, AKIS is limited in its consideration of the heterogeneity among agents, the institutional contexts that condition agents' behavior, and the learning processes that determine agents' capacity to change and innovate.

\section{Innovation System Approach}

The conventional pipeline approach to agricultural research, technology development, and dissemination has produced numerous success stories, but it has serious limitations for broad-based sustained agricultural growth and poverty reduction.

The innovation system approach has emerged as a holistic tool for understanding and, to a limited extent, analyzing knowledge and innovation for agricultural growth and poverty reduction. An innovation system approach considers innovation as a systemic process, recognizing that innovations can emerge from many sources, complex interactions, and knowledge flows. This approach involves a network of organizations and individuals focused on bringing new products, new processes, and new forms of organization into economic use, together with the institutions and policies that affect the behavior and performance of the network. The innovation systems approach broadens the NARS and AKIS perspectives by focusing on (a) the processes by which diverse agents engage in generating, disseminating, and utilizing knowledge; (b) the organizational and individual competencies of such agents; (c) the nature and character of their interactions; and (d) the market and nonmarket institutions that affect the innovation processes. The approach focuses on interactions, knowledge-sharing, and continuous learning. It addresses novel issues, such as the capacity of individuals and organizations to learn, change, and innovate; the nature of iterative and interactive learning processes among innovation agents; and the types of interventions that enhance such capacities and processes.

Closely associated with the innovation systems approach is the Integrated Agricultural Research for Development (IAR4D) paradigm, which puts farmers and users at the center of innovative practices. The IAR4D approach encourages learning through the interchange of ideas, successes, and failures among stakeholders. Capacity, in terms of knowledge and information, has to be strengthened in farmers and other operators in the agricultural value chain to enable them to operate efficiently in the knowledge economy.

Because of its evolutionary character, the innovation systems approach and processes are context-specific and historically determined. In particular, the conditions of agriculture in developing countries are so diverse and complex that they may hamper implementation of the approach. In these countries, interactions among actors are limited (with the exception of social networking), many of the institutions relevant to the innovation system are weak or nonexistent, empirical findings on agricultural innovation systems in developing countries are scarce, and the culture of knowledge sharing is limited.

Instead of considering the innovation systems approach as yet another "must-use" paradigm, and debating its merit as the definitive means of thinking about agricultural development, this synopsis calls for innovation systems thinking to be considered as just one approach to creating the policy and institutional conditions that will allow the emergence, coexistence, and evaluation of diverse ways of creating, accumulating, and utilizing knowledge for agricultural growth. The intellectual challenge is to stop the debate and polarization of ideas about innovation and, instead, engage in institutional learning to communicate concepts, undertake effective diagnosis, design pro-poor innovation systems, and learn through practice and 
networking. Thus, there is a need to end "innovationbranding" battles and recognize both the diversity of innovation experiences (thus avoiding the idea of "one size fits all") and the importance of knowledge-sharing practices and the adaptation of knowledge to specific contexts to bring about development.

\section{CONFERENCE PAPERS ON AGRICULTURAL KNOWLEDGE AND INNOVATION CONCEPTS}

- Evolution of Systems Thinking toward Agricultural Innovation Systems, by Howard Elliot

- Enabling Agriculture: From Institutional to Conceptual Systems for Knowledge and Innovation, by Regina Birner

- Knowledge and Innovation for Agricultural Development, by Kwadwo Asenso-Okyere

- Knowledge and Innovation for Poverty Reduction, by Joachim von Braun

- Using Knowledge and Innovation in Pro-poor Agricultural Research, by Monty Jones

- Success Factors for Knowledge Management in Development Organizations, by Joachim Hofer

- Up-scaling Knowledge and Innovation for Development, by Andrew Barnett

- Knowledge Sharing and Innovation in the CGIAR: ICT-KM Program Interventions, by Enrica Porcari

- Next Steps for Strengthening Agricultural Innovation Systems: A Road Map for Investigators and Investors, by Andy Hall 


\section{3}

\section{ORGANIZATIONAL}

\section{INNOVATION}

$\mathrm{E}_{\text {of }}^{\text {fif }}$ fficiency and effectiveness in the operation and management of agricultural organizations necessitate innovation (Box 1). These organizations include those that cover research, extension, education, input supplies, marketing, and collective action (farmer-

\section{Innovations enable organizations to pursue their specified goals efficiently.}

take advantage of the environment within which it operates. Strengths and opportunities are exploited, and weaknesses and threats minimized to improve the competitive posture of the organization. Once the long-term goals of the organization are determined, short-term priorities can based organizations, community-based organizations, and civil society organizations). Innovations enable organizations to pursue their specified goals efficiently. Results-oriented organizations, whether in the public or private sectors, institute appropriate, transparent governance structures that reward hard work and success. Such organizations efficiently manage resources, have built-in capacity-strengthening activities for staff, regularly monitor and evaluate activities, and occasionally conduct impact assessments in relation to their mandate to demonstrate the relevance of their operations.

Organizational innovations may involve issues such as capacity strengthening, strategic planning, priority setting, R\&D management, financing, monitoring, evaluation, and collective action. Planning is an effective tool for organizational management. Strategic planning and scenario planning are useful in setting long-term goals for an organization. SWOT analysis (of strengths, weaknesses, opportunities, and threats) is used to guide an organization in positioning itself to be set based on available resources. Next, principles of managing for impact should be applied to ensure that scarce resources are used efficiently. Organizations must also monitor and evaluate their operations to ensure that their impacts align with their mandates and strategic plans, and this includes designing appropriate indicators for use in evaluating impact.

Capacity strengthening to upgrade staff skills must also be part of the organization's agenda and must be diligently pursued. For instance, in a research organization, staff must develop skills in research management, proposal development, field data collection, data management and analysis, report writing, and advocacy. Similarly, management staff require a variety of skills including negotiation and advocacy.

A major area of organizational innovation is extension. Extension-also known as agricultural advisory services-was originally conceived as a service to "extend" research-based knowledge to the rural sector to improve farmers' lives. It thus includes components of technology transfer, broader rural 


\section{BOX I. Rural Knowledge Networks and Agricultural Innovation: The Case of Bolivia}

The Bolivian Agricultural Technology System (SIBTA) is an interesting case of organizational innovation. The Bolivian experience suggests that the role of government in agricultural innovation can be enhanced if public support to agricultural research and extension is partly delegated to regional semi-autonomous foundations. This case also demonstrates the need for effective knowledge management by creating learning spaces among multiple agents, including smallholder farmers. SIBTA has experimented with the idea of tapping local or indigenous farmer knowledge systems in an attempt to harmonize tacit knowledge with the explicit knowledge of researchers and extension workers. In addition, SIBTA has attempted to investigate whether being embedded in and connected to social networks has an effect on the rate of application of agricultural technologies in Bolivia.

The Bolivian experience generated an interesting hypothesis worth investigating further: centering farmers within learning networks makes it possible to accelerate the rate of application and effectiveness of new technologies. This hypothesis has far-reaching implications for rural development actors, who often fail to forge collaborations with stakeholders and networks, or to incorporate knowledge-sharing components into their thinking. Actors need to forge partnerships together and share knowledge instead of competing for funding, as they often do.

development goals, management skills, and nonformal education. The traditional view of extension in SubSaharan Africa was very much focused on increasing production, improving yields, training farmers, and transferring technology. Today's understanding of extension reaches beyond technology transfer to facilitation, and beyond training to learning. It includes assisting with the formation of farmer and communitybased organizations, dealing with marketing issues, and partnering with a broad range of service providers and agencies (see Boxes 3 and 5). Provision of market and trade information to farmers is important. Farmers require a wide range of knowledge from different sources; they also need support in integrating the knowledge. Therefore, extension can be defined as the system that supports people engaged in agricultural production in solving problems and in obtaining knowledge, skills, and technologies to improve their livelihoods and well-being.

Broad organizational reforms in extension are ongoing; they aim to address the failure of earlier models and incorporate new thinking and approaches in rural development to increase the equity, efficiency, and quality of extension. The main reforms include the following:

1. Decentralization to improve client participation, promote accountability of providers, and improve efficiency

2. Privatization of services, which involves costrecovery schemes, including transferring ownership to private entities, charging a fee for service, sharing costs, and procuring financing from farmers

3. Outsourcing schemes, which involve funding by one agent and provision of services by anotherin terms of both contracting in and contracting out-and pluralism in the delivery of extension services

4. Demand-driven models, which involve a participatory approach, bottom-up planning, and empowerment of poor farmers 
Reforms have generally failed to bring about institutional change in extension. The scope of innovation was enlarged, but it has not affected the dominance of the linear paradigm (research-extensionfarmer). Extension continues to be evaluated based on technology adoption - that is, a concentration on technology transfer.

Traditional extension services have been criticized for excluding poor people and being supply-driven, highly centralized, and nonparticipatory (dominated by a single channel of knowledge transfer). Demanddriven advisory services, on the other hand, are thought to be bottom-up, pluralistic in the choice of delivery channels, flexible in the choice of funding sources, and inclusive of vulnerable groups. Two case studies on demand-driven innovation are presented below from experiences in Africa (see Box 2) and India (see Box 3). More research is needed to determine how farmers can be empowered to demand the type of services they need, how suppliers can respond to farmers' needs, and how such schemes can be innovatively financed.

Other forms of communication and knowledge flows have been found to be effective in agricultural innovation systems in developing countries. Social networks have been used to disseminate information and reach consensus among farmers in formal and informal associations (see Box 6). Such interactions have enabled information spillover across locations, which is a crucial means of advancing agriculture in developing countries. Information and communication technologies (ICT) have provided another avenue for sharing information in agriculture. ICT can provide users with good and timely information on production and postharvest technologies, markets, prices, and other operators in the food and agricultural value chain. However, there are numerous impediments to the spread of ICT infrastructure and services to rural areas, especially in light of low rural incomes, widely dispersed populations, and lack of access to electricity.

\section{BOX 2. Demand for Advisory Services in Africa: The Cases of Nigeria and Uganda}

In the 1990s and early 2000s, governments and development partners in Africa started reforming traditional extension services to address their major weaknesses: a supply-driven and top-down approach, limited financial and human capacity, and lack of access by women and other vulnerable groups. One reform includes demanddriven approaches and plurality of service providers (for example, the public, nongovernmental organizations [NGOs], farmer organizations, and private providers), pluralistic funding, and targeting of vulnerable groups.

Demand-driven advisory services (DDASs) have been implemented in Uganda and Nigeria as pilot projects with donor support. In Uganda, under the National Agricultural Advisory Service (NAADS), DDAS has contributed to the increased capacity of participating farmers, though it has faced challenges, including low effective demand for marketed services, low capacity to provide extension services, and weak government commitment in support of the innovation. From the experiences of Uganda and Nigeria, it is possible to draw the following lessons:

- Flexibility in service delivery is important in making innovations workable.

- The effectiveness of DDAS depends, in part, on access to assets and human capital.

- Complementary programs should be in place so as to make assets accessible to poor farmers.

- Private-sector participation in the provision of extension services can be limited by "free-riding," which arises from the possibility of spillover effects from knowledge acquired through pluralistic channels. 


\section{BOX 3. A Decentralized, Farmer-Led, Market-Driven Extension System: The Case of India}

Established in 1998, the Agricultural Technology Management Agency (ATMA) involved close and effective partnerships among the Government of India, the World Bank, NGOs, farmers groups, and other stakeholders. The ATMA model is a striking case of organizational innovation, involving a decentralized, farmer-led, and marketdriven extension system. The model promotes a major shift in the focus of and approach to extension in India through:

- a shift away from transferring technologies for major food crops toward helping small-scale and female farmers diversify output into higher value crop and livestock enterprises;

- a decentralized extension system to create awareness and then train male and female farmers about how to pursue new enterprises;

- the development of social capital by helping male and female farmers to organize themselves into groups; and

- more emphasis on sustainable natural resource management practices.

The major positive impacts of the ATMA model include

- crop diversification in favor of high-value enterprises, such as horticulture;

- major increases in rural employment; and

- increased farm incomes (6 percent per year in project districts compared with I percent in nonproject districts).

Given the success of the ATMA model, the Government of India has been progressively scaling-up the model to all 588 rural districts in India. These efforts, however, are severely constrained by lack of government resources to train and support extension workers, support local extension programs and activities, and partner with NGOs to organize farmers into groups.

\section{CONFERENCE PAPERS ON ORGANIZATIONAL INNOVATION}

- Enabling Small Producers to Engage with Markets: The Need for Multiple Skill Sets, by Geoffrey Heinrich, Edward Charles, Zamede Abebe, and Rupert Best

- Extension Reforms to Improve Knowledge and Innovation for Development, by Kristin Davis

- Building Capacities for Innovation: Examples from the Field, by Suresh Babu

- Accelerating Innovation with Prize Rewards, by William A. Masters

- Rural Knowledge Network and Agricultural Innovation: Lessons from Bolivian Smallholder Agriculture, by Frank Hartwich and Mario Monge

- A Decentralized, Farmer-led, Market-driven Extension System: The ATMA Model of India, by Burton E. Swanson, K. M. Singh, and M. N. Ready 
TECHNOLOGICAL

INNOVATION

\section{TECHNICAL KNOWLEDGE}

$A_{\text {an important role in innovation, }}^{\text {lthough indigenous knowledge plays }}$ it alone is insufficient to catalyze the developments required in the complex food and agricultural system. Science and research produce new knowledge that can be disseminated along the food and agricultural value chain to support innovation processes to increase productivity. During the Green Revolution of the 1950s and 1960s, agricultural research played a major role in developing the crop varieties that spearheaded dramatic increases in Asian wheat and maize production, thereby improving the livelihoods of farmers. Countries have been urged to invest in agricultural R\&D as a way of unlocking hidden agricultural and socioeconomic potential and reducing rural poverty. Private research organizations are emerging in certain developing countries like India, but opportunities also exist for the public and private sectors to work together in some form of partnership.

The benefits of the Green Revolution included doubling production; preserving virgin land; raising farm incomes, wages, and the demand for rural services; and reducing food prices. Can the "gene revolution"
Science and research produce new minated and agricultural value chain to support innovation processes to increase productivity. do better? The Gene Revolution aims to lower net production costs, raise effective yields, raise net farm incomes, reduce the use of pesticides and herbicides, and lower consumer prices. Most transgenic $R \& D$ involves either maize or soybeans. Biotechnology has led to increased maize yields of 8-10 tons per hectare compared with single cross yields of 5-7 tons per hectare and open pollinated yields of $1-1.5$ tons per hectare. And on another front, conventional breeding researchers under the CGIAR's HarvestPlus Program have developed biofortified varieties of a number of staple crops to enhance nutrition security in developing countries.

One of the most important agricultural inputs is the seed or planting material on which farming fundamentally depends (Box 4). The framework for seed security is availability, access, and quality. Farmers use their own seed saved from prior seasons, they procure saved seed from other farmers, or they purchase seed through formal channels.

\section{ENHANCING INVESTMENT IN RESEARCH AND DEVELOPMENT}

Investment in agricultural $R \& D$ constitutes a viable means of increasing productivity for growth and 
poverty reduction. Returns to investment in R\&D have been found to be high in developing countries. Despite the high payoffs, however, agricultural R\&D is grossly underfunded. Private investment in developing-country $R \& D$ is very limited. With the exception of a few developing countries (notably India and China), public spending on agricultural R\&D (which funds 94 percent of the agricultural $R \& D$ in the developing world) has experienced sluggish growth. As a group, developing countries invested only 0.56 percent of their agricultural GDP in research in 2000 (including donor contributions).

The reason why investment in agricultural R\&D has remained low can be explained by several factors. First, the political economy of public expenditure decisions tends to emphasize short-term payoffs and subsidies, while agricultural R\&D investments are both longterm and risky. In addition, in poor countries, farmers have limited bargaining power to lobby for increased investment in agriculture. Second, trade distortions and national policies that reduce incentives to farmers in developing countries can act as a disincentive to both public and private investment in R\&D. Third, because of the strong spillover effects of benefits from agricultural
R\&D, many nations have been free-riding on the efforts of others. The CGIAR, for example, has generated over half of the new technologies used in agriculture in the developing world.

\section{BENCHMARKING INNOVATIONS}

The International Assessment of Agricultural Science and Technology for Development (IAASTD) was initiated by the World Bank in collaboration with a range of multistakeholder organizations and representatives of governments, civil society, and private sectors around the world with the purpose of assessing regional needs for agricultural science and technology ( $\& \& T)$. The ultimate goal of IAASTD is to reduce hunger and poverty; improve rural livelihoods; and facilitate equitable and sustainable development by generating and ensuring access to and use of agricultural knowledge, science, and technology. IAASTD supports the view that S\&T needs to be embedded within a broader development agenda in order to continue to fuel advances in productivity, competitiveness, and sustainable livelihoods.

Attempts have been made to benchmark R\&D in developing countries through IFPRI's Agricultural Science and Technology Indicators (ASTI) initiative.

\section{BOX 4. Monsanto Agricultural Technology}

Technological innovations in agriculture are diverse and require the assistance of government institutions, private companies, agricultural experts, NGOs, and others. Monsanto is an agricultural technology company focusing on seed, crop protection, biotechnology, and animal agriculture. Monsanto has established strategic platforms in high-value, large- and small-scale crops (that is, soybeans, cotton, and corn, on the one hand, and vegetables on the other). The company has also developed R\&D platforms in biotechnology and molecular and conventional breeding. Monsanto provides farmers in Africa (and the rest of the world) with seed technology and herbicides to make them more productive and competitive. One of their projects in India resulted in a 54-percent yield increase and 60-percent profit increase for farmers.

Monsanto also engages in partnerships in order to meet the needs of farmers through training and distribution of improved seed and chemicals. Partnerships are used to develop appropriate products, such as small packs of seed and herbicides at affordable prices, and to support the growth of distribution channels through training and by supplying small stockists of agricultural inputs. 
Such benchmark results allow countries to assess their agricultural R\&D systems in the context of other countries and regions in terms of human and financial capacity and institutional developments in agricultural R\&D. Plans are under way to establish a similar initiative for agricultural extension. It is important that the indicators are strongly linked to economic performance or demonstrate the interconnectedness of the economy in order to guide resource-scarce countries in making decisions about investments in agricultural $R \& D$ in the face of competing demands.

It is also important to benchmark innovations in general, so work in this area is much needed. Such initiatives should cover outcome, process, and input indicators - areas in which policymakers have expressed interest. Many R\&D and innovation indicators are based on quantitative measures, but they need to be expanded to incorporate key insights from the innovation systems perspective. The framework for benchmarking R\&D and innovation should take advantage of the power of qualitative methods in explaining some of the quantitative outcomes. Social network analysis or influence mapping has been used to investigate the direction of influence in the innovation process, but the diagnostic and predictive power of the methods needs to be strengthened. It is obvious that more research is needed to explore different approaches to benchmarking agricultural innovations. Renewed focus on evidence-based research has led to a resurgence of donor interest in supporting the development of databases. Nevertheless, the data must be relevant and up to date if it is to be useful.

\section{CONFERENCE PAPERS ON TECHNOLOGICAL INNOVATION}

- Agricultural Knowledge and Innovation for Poverty Reduction, by Ruth Meinzen-Dick

- Private-Sector Development: The Monsanto Company, by Kinuya Mbijjiwe

- ICT and Agriculture Innovation: Trends and Opportunities, by Kerry McNamara

- Innovation, Incentives, and Indicators: Improving the Analysis of Technology and Innovation in Developing-Country Agriculture, by David J. Spielman

- Measuring Public Agricultural Research Investments: A Revised Global Picture, by Nienke Beintema and Gert-Jan Stads

- Will the Gene Revolution Reach the Poor?, by Terri Raney

- Innovative Seed Responses after Disaster, by Tom Remington

- Agriculture for Development: WDR 2008 and IAASTD, by Eija Pehu

- How Does the Private Sector Contribute to Knowledge and Innovation to Advance Agricultural Development?, by Lemlem Sissay

- Building Blocks toward a Structured Trading System in Eastern Africa, by Anne Mbaabu

- Extension from an Innovation System Perspective, by Rasheed Sulaiman

- Indicators for Assessing the Status of Extension Systems and Quality of the Service, by Magdalena Blum

- Participatory Research through Farmer Research Groups, by Kiyoshi Shiratori

- Determinants of Demand for Advisory Services in Africa, by Ephraim Nkonya, Samuel Benin, Dayo Phillip, John Pender, Tewodaj Mogues, and Edward Kato

- Globalization of Private Agricultural Research and Innovation: Opportunities for Developing Countries?, by Carl E. Pray

- Biotechnology, Biosafety, Knowledge, and Innovation, by José Falck Zepeda 


\section{INSTITUTIONAL}

\section{INNOVATION}

\section{THE NATURE OF INSTITUTIONS}

nstit

nstitutions (once again defined as the

system of rules that constitute the environment within which innovation occurs) include laws, regulations, traditions, customs, beliefs, norms, and other societal nuances that prohibit, permit, or require certain actions. Whether formal or informal, such institutions are recognized and generally followed by members of the community. Institutions provide behavioral indicators, order, and stability within the complex and uncertain world of economic and social interactions. A new, broad-based perspective on agricultural innovation emphasizes the role of diverse actors, networks, partnerships, and linkages in the production, dissemination, and use of information and knowledge along the food and agricultural value chain. Broader institutions are also relevant, including those related to agricultural policy and the dynamics of power, given that building the trust necessary to support collaborative innovation is more problematic when large power differentials exists among actors.
Institutional analysis with respect to innovations deals with several questions including the following:

- How do innovations come about?

- Which actors are involved in the innovation system, and what roles do they play?

- What are the "rules" that guide the behavior and practices of actors?

- How are smallholders engaged in and affected by the process of institutional learning?

Institutional innovation is an ongoing process with a number of inherent constraints. For example, financial markets are constrained by information asymmetries; smallholders may be incapable of managing risk due to lack of ameliorating options, such as insurance schemes; input markets are inefficient; and producer organizations are weak.

The institutional setting plays a central role in shaping critical processes for innovation systems - that is, interactions, knowledge-sharing, and continuous learning to bring about changes in a desired direction. New institutions should be established to promote 
innovation, and policy channels need to be strengthened through capacity building.

In discussing institutional innovation, the roles of public-private partnerships, social networks, and participatory research are important (Box 5). It is equally important to look at policy issues with regard to how innovation systems can bring different actors together and how innovations can be brought within food and agricultural-commodity value chains.

\section{PARTNERSHIPS FACILITATE INNOVATION}

Partnerships are an important component of institutional innovation for agricultural growth and poverty reduction. The benefits of partnerships include not only knowledge and risk-sharing advantages, but also realization of economies of scale in resource use, exploitation of complementarities of objectives and expertise, and coordination (realization synergies) advantages. Ideally, partnership should involve all actors and stakeholders directly involved in the generation, accumulation, dissemination, and utilization of agricultural technologies.
So far, there have been limited partnerships between institutes of higher education and extension systems, between extension workers and community-based organizations, between vocational/technical schools and extension systems, between NGOs and the public sector, between the private sector and producer organizations, and so on. Lack of incentives is an important contributing factor to weak partnerships among stakeholders.

Public-private partnerships in agriculture can be strengthened in the higher education system through technical apprenticeships and internships. Such partnerships offer important opportunities for reducing the cost of research, promoting innovation and creativity, and enhancing the impact of research on the poor. To achieve these goals, public- and private-sector partners need to learn from existing partnership experiences and account for the costs and risks associated with partnering.

Co-funding and cooperation of public institutions, foundations, and private enterprises with a view to expanding knowledge and innovation systems should

\section{BOX 5. Social Networks in Knowledge Sharing}

Rural social networks provide informal channels for the transfer of information and technologies (for example, farmer-to-farmer transfer). This implies the need to target groups and individuals embedded in social networks. Lessons from Bolivian smallholder agriculture (Box I) underline the need to promote rural knowledge networks and agricultural innovations, with recommendations that research endeavors and policies pay attention to the following hypotheses:

- Research and extension alone are insufficient to bring about pro-poor growth in rural areas.

- The need exists to adapt innovations to the needs of resource-poor farmers and to their innovative capacities.

- Social interactions and networks can contribute to the adoption of innovations.

- Development-oriented NGOs have the potential to contribute to productivity increases.

Social networks and the noncommercial exchanges have collective value in facilitating knowledge sharing and the adoption of innovations and thus constitute important social capital that should be exploited. 
also play an important role in advancing agriculture in developing countries. A case study from Morocco provides an interesting model of institutional innovation and partnership (see Box 6). The case of tomato value chains in Morocco amply demonstrates the importance of partnership, interaction, and knowledge sharing to improve efficiency in the process of creating value. The case demonstrates

\section{Co-funding and cooperation of public institutions, foundations, and private enterprises with a view to expanding knowledge and innovation systems should also play an important role in advancing agriculture in developing countries.}

that improved tomato yields and quality resulted from effective partnerships between farmer organization, the private sector, institutions of higher education, and government ministries. In addition to the Morocco case, the floriculture industry in Ethiopia demonstrates the importance of partnership and knowledge sharing in the production and marketing of a high-value crop (cut flowers).

\section{BOX 6. Adding Value to Tomato Production in Morocco: A Model of Partnership in Knowledge and Risk Sharing}

Morocco offers the case of a successful experience in public-private partnership, farmer and business sector collaboration, and effective value addition through a knowledge sharing process and innovation system that generated benefits to tomato farmers, the private sector, and consumers.

In Morocco supermarkets, processors, and exporters contracted with wholesalers to ensure timely delivery of quality tomatoes. In turn, the wholesalers entered into contractual agreements with farmer organizations or individual farmers to ensure timely delivery of quality tomatoes in the right quantities. For example, Aicha AgroIndustry provided farmers with technical advice and cash advances to partially cover the cost of drip irrigation and enable farmers to purchase timely inputs. Farmers sold their produce to the contracting wholesaler and received premium prices based on improved quality and preferred timing of delivery. In addition, Aicha AgroIndustry forged viable partnerships with researchers at the Faculty of Agronomy at Meknes University to engage in adaptive research, run demonstration plots, train and provide technical advice to farmers, and analyze the soil nutrient content of new farm plots. In addition to partially funding research, Aicha Agro-Industry forged a partnership with the Ministry of Agriculture to train staff, and made research results available for use in the public sector. The institutional arrangement benefited all agents involved in the value chain. Tomato yields doubled, and quality improvements were substantial. Another interesting outcome of the Morocco model was that partners not only shared knowledge, but also risks: farmers were able to sell their products at a guaranteed price, while wholesalers were assured timely delivery of high-quality tomatoes in the right quantities. 


\section{CONFERENCE PAPERS ON INSTITUTIONAL INNOVATION}

- Extension from an Innovation-System Perspective by Rashid Sulaiman

- Agricultural Innovations within a Supply Chain: The Case of Agropole in Morocco, by Marie-Hélèn Collion and Noureddine Ouazzani

- How Does the Private Sector Contribute to Knowledge and Innovation to Advance Agricultural Development?, by Lemlem Sissay

- Spatial Knowledge Spillover and Agricultural Growth, by John Ulimwengu and Prabuddha Sanyal

- How Can Technological and Socio-institutional Innovation Processes Have More Impact at the Local Level?, by Ann Waters-Bayer

- What Is the Effect of Gender on Knowledge and Innovation?, by Maria Fernandez 


\section{POLICY INNOVATION}

Dolicies play a major role in promot-

ing agriculture. There are many problems that can be resolved and issues that can be facilitated or promoted with policies alone, removing the need to design specific programs to deal with them. Sound, pragmatic policies require innovations to ensure their appropriateness, relevance, and timeliness (see Box 7). Through monitoring and evaluation, policies can be used to rectify programs whose implementation is faltering. In this way, the need to redesign projects - which would take time and be costly-is eliminated.

The fertilizer sector offers a good example of how an innovative policy can be enacted. Fertilizer subsidization is an issue that has occupied the attention of policymakers, development practitioners, and farmers in developing countries, given the extent of nutrient mining occurring and the need to increase productivity. Although subsidizing fertilizer may be desirable, care must be taken that such action does not distort the market and lead to excess demand. This implies the need for an innovative policy, such as one that allows the intended farmers to participate in the market but at the same time promotes investment in systems that shift the supply curve. An example of such a policy in relation to subsidies is the use of redeemable vouchers targeting poor people; the vouchers can be used in the market alongside cash, thereby avoiding market distortions or disincentives to private-sector participation. 


\section{BOX 7. IAASTD Science and Technology Policy}

The IAASTD initiative has a number of strategies for S\&T policy relevant to agricultural knowledge and innovation processes:

- Policies to support more and better investments in developing-country agriculture are indispensable.

- S\&T must play a key role for productivity growth, competitiveness, and sustainable livelihoods, which require innovative approaches involving diverse actors; this can be achieved through an appropriate R\&D investment policy.

- Linking formal and informal knowledge is an important factor in agricultural development.

- Technology development needs to be embedded in a broader development and innovation systems context through the right policies.

CONFERENCE PAPERS ON POLICY INNOVATION

- Policy Innovations for Fertilizer Subsidy Management in Developing Countries, by Balu Bumb

- Responding to the Agricultural Crisis Using Farmers' Innovation: Lesson for Senegal's Agricultural Research and Policies, by Papa Nouhine Dieye 
STRENGTHENING

CAPACITIES FOR KNOWLEDGE

AND INNOVATION

$\mathrm{l}_{\mathrm{at}}^{\mathrm{t}}$ is clear that adequate capacities are needed at all levels to address the technological, organizational, institutional, and policy problems that face smallholder farmers in developing countries. While the need to strengthen capacity is recognized, little action has been taken to address these needs,

Individual capacities, including thematic skills, are needed to strengthen key actors in the innovation system. including identifying specific gaps. Thus, the need exists to first identify capacity gaps at the country level, and this poses several challenges. Capacity gaps at the country level should go beyond the basic technical and scientific skills needed to design and implement research. Organizational and managerial skills are also needed, as is the institutional capacity to identify, accommodate, and facilitate innovation processes at various intracountry levels. In addition, system-level capacities need to be identified to encourage and motivate the development of policies and practices for developing and enabling an environment for pro-poor innovation.

Individual capacities, including thematic skills, are needed to strengthen key actors in the innovation system. Such skills involve quantitative, qualitative, and process-related analyses of the innovation system. Organizational capacities that go beyond technical skills are also needed to develop innovation processes and connect them at the national level. Capacities at the systems level include the capacity to develop S\&T policies, practices, and processes that will enable the various actors and institutions to function effectively.

At the farmer level, a wide variety of skill sets are needed, including group management; internal savings and lending; basic business skills; and the ability to access, adapt, and apply new technologies and to manage natural resources. Group dynamics and leadership are important skills for individuals at the local level; such skills are also important for extension agents, NGOs, and others working at the local level through farmer organizations.

Capacity is also required to enable actors to forge partnerships, profit-sharing arrangements, and other collaborations between private- and public-sector researchers. The capacity to learn from successes and failures of actors in the innovation system, and documenting institutional memory for effective use through learning processes, would strengthen the institutional innovation mechanism.

The development of no-till packages for smallscale farmers in Argentina has illustrated the need for greater understanding of the structure and dynamics 
of innovation systems at local levels (see Box 8). The public-private partnership developed in Latin American countries to identify markets and new products for export also underscores the importance of strengthening the capacity of public- and private-sector agents to negotiate, identify problems, understand each other's perspective, and effectively establish partnerships in support of successful innovation (see Box 9). An example from South India using watermanagement challenges shows that farmer-led innovations need to be encouraged by public research to improve the effectiveness of innovation systems for natural resource management (see Box 10).

An important component of capacity development takes place within universities or institutions of higher learning, so such institutions need to innovate to be more efficient. This process of "building the capacity to build capacity" ensures effective pedagogy for agriculture. The use of participatory methods of teaching tends to increase retention of student knowledge. Curricula should also be developed in a participatory manner, and curricula should be revised based on feedback from students and actors in the agricultural value chain, including farmers. This will enrich curricula and make them more relevant to the needs of society.
Students must also be given practical learning experience through direct engagement-a particularly critical factor in the rapidly changing fields of technology. Experiential learning can be promoted more readily in universities that have direct linkages with the production sector. This makes community linkages even more critical to the effective functioning of universities. If students are to be able to participate in curricula development, appreciate local problems, and offer solutions, they need the opportunity to interact with farmers and other actors in the food and agricultural value chain.

Graduates of agricultural sciences fill a variety of positions in research, policy analysis, extension, and other areas in the public and private sectors. Continuous education allows them to remain abreast of knowledge developments in the sector. To this end, universities can mount short and specialized courses to build the capacity of mid-level researchers.

Developing a well-functioning innovation system will require strengthening the capacity of actors and institutions at the individual, organization, and systems levels. The importance of continuous investment and a long-term perspective toward capacity strengthening cannot be underestimated.

\section{BOX 8. Developing Capacity for No-Till Packages for Small-Scale Farmers in Argentina}

Experience from Argentina shows that capacity building and complementary assets were needed to effectively promote no-till packages among small-scale farmers. Tilling soil with plows and harrows often turns the topsoil and moves it downwards. No-till technology allows small-scale farmers to preserve and utilize nutrient-rich topsoil when cultivating crops. In developing the technology in Argentina, a participatory research approach was used.

The necessary networks and linkages were established between the researchers and farmers in Argentina, and capacity in the no-till technique was built in both groups through learning routines or platforms. To facilitate these arrangements, extension personnel acted as network and innovation agents, serving as a bridge between the researchers and the farmers. 


\section{BOX 9. Building the Capacity to Forge Public-Private Partnerships in Latin America}

Capacity strengthening must be specific to a partnership. If partnerships are to work effectively, the capacity to partner must be developed among the individual partners in public-private partnership (PPP) arrangements. An example in Latin America aiming to enhance market access began with a needs assessment for capacity strengthening for the partnership. Both partners participated in a diagnostic study through which a horizontal learning platform was established. The process brought about increased cohesion and allowed specific capacity needs of common interest to the partners to be identified.

\section{BOX 10. Developing Farmer-Based Organizations in South India}

In resource-scarce situations, farmer-based organizations (FBOs) provide an opportunity to bringing about innovations in agriculture. In South India, one of the major activities of an FBO included frequent dialog among members to promote their interests. In an initiative involving community water management, the capacity of the partners to link formal research outcomes and innovations from farmers was built through a participatory approach that included farmers, researchers, extension officers, and policymakers. Another aspect of strengthening capacity was resource mobilization for the implementation and dissemination of innovative water-management ideas.

\section{CONFERENCE PAPERS ON BUILDING CAPACITIES FOR KNOWLEDGE AND INNOVATION}

- Capacity Building for Innovation in Natural Resource System Management: The Case of Banda College, University of Malawi, by George Y. Kanyama-Phiri

- Building Capacities for Innovation: Examples from the Field, by Suresh Babu

- Exploring Innovation Capacity in the Ethiopian Dairy Systems, by Tesfaye Lemma, Ranjitha Puskur, and Dirk Hoekstra

- Building Capacity for Innovation in Food Technology and Nutrition Security, by Kumbe Martin and Ruth Oniang'o 


\section{CONCLUSION}

\section{AND THE WAY FORWARD}

$\mathrm{T}$ he conference on "Advancing Agriculture in Developing Countries through Knowledge and Innovation" provided a forum to shed more light on issues concerning innovation for agricultural development. The major focus of the conference was the recognition of the critical importance of knowledge and innovation in the pursuit of agricultural development for growth and poverty reduction. The papers explored the interplay of technologies, organizations, policies, institutions, and system dynamics in innovation processes, without advocating a particular paradigm. The presenters made valuable contributions, and the ensuing discussions produced innovative ideas and practices, charting numerous next steps.

Participants noted the importance of partnerships, platforms, coalitions, and linkages through which to share knowledge and innovation. In addition, the need was raised to understand and evaluate innovation processes, as well as the need to develop indicators and benchmarks with which to evaluate these processes. Moving from "best practice" to "best fit" approaches was a common theme.
Several actions were suggested to operationalize the innovation systems approach and enhance its usefulness for poverty reduction. These included the need (a) to focus on the interplay of institutions, (b) to ensure openness to the adoption of technology, (c) to form and take advantage of partnerships, (d) to empower farmers, (e) to maintain a market orientation, (f) to reward knowledge creators and innovators, $(\mathrm{g})$ to pursue regional cooperation, and (h) to be biased in favor of urgent action.

The need to evaluate the processes through which innovation occurs was recognized, as was the difficulty of carrying out an evaluation through conventional means in the absence of an obvious counterfactual. One of the next steps is thus to develop the capacity to conduct research using a systems approach, and to develop the tools with which to empirically assess the way innovation occurs in agriculture. Such research will contribute tremendously to knowledge.

In addition to the publication of this synopsis, the conference papers will be edited and published as a book, and three policy briefs will be issued on various topics on knowledge and innovation in agriculture. 


\section{About the Authors}

Kwadwo Asenso-Okyere is the director of the International Service for National Agricultural Research (ISNAR) Division of the International Food Policy Research Institute (IFPRI), based in Addis Ababa, Ethiopia; Kristin Davis is a research fellow within IFPRI's ISNAR Division; and Dejene Aredo is an international consultant and associate professor in the Department of Economics at Addis Ababa University. 

INTERNATIONAL FOOD

POLICY RESEARCH INSTITUTE

IFPRI $^{\circ}$

sustainable solutions for ending hunger and poverty

Supported by the CGIAR

HEADQUARTERS

2033 K Street, NW

Washington, DC 20006-1002 USA

Tel.: +1-202-862-5600

Fax: +1-202-467-4439

Email: ifpri@cgiar.org

IFPRI ADDIS ABABA

P.O. Box 5689

Addis Ababa, Ethiopia

Tel.: +251-11-6172500

Fax: +251-11-6462927

Email: ifpri-addisababa@cgiar.org

www.ifpri.org

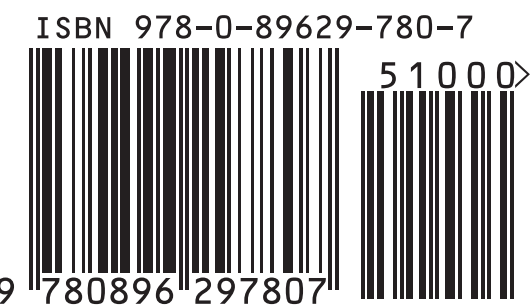

